Uniwersytet Przyrodniczo-

Humanistyczny w Siedlcach

Siedlce University of Natural

Sciences and Humanities

https://bazawiedzy.uph.edu.pl

\begin{tabular}{|l|l|}
\hline Publikacja / Publication & $\begin{array}{l}\text { The place of comeniology in contemporary humanities, } \\
\text { Sztobryn Sławomir }\end{array}$ \\
\hline $\begin{array}{l}\text { Adres publikacji w Repozytorium URL } \\
\text { / Publication address in Repository }\end{array}$ & https://bazawiedzy.uph.edu.pl/info/article/UPHf3b9df8591c14bf4890ec566e84ed2ff/ \\
\hline $\begin{array}{l}\text { Data opublikowania w Repozytorium / } \\
\text { Deposited in Repository on }\end{array}$ & 22 paź 2021 \\
\hline Rodzaj licencji / Type of licence & Attribution-NoDerivs (CC BY-ND 3.0) \\
\hline Cytuj tę wersję / Cite this version & $\begin{array}{l}\text { Sztobryn Sławomir: The place of comeniology in contemporary humanities, } \\
\text { Siedleckie Zeszyty Komeniologiczne seria PEDAGOGIKA, no. 6, 2019, pp. 35-42 }\end{array}$ \\
\hline
\end{tabular}




\title{
THE PLACE OF COMENIOLOGY IN CONTEMPORARY HUMANITIES
}

\author{
MIEJSCE KOMENIOLOGII \\ WE WSPÓŁCZESNYCH NAUKACH HUMANISTYCZNYCH
}

DOI: $10.5604 / 01.3001 .0013 .6242$

\begin{abstract}
Comeniological research can be recognized as the one that belongs to the broadly understood humanities. Due to the factual diversity of Comenius' creative output, which is the subject of many scientific specialties, it can be included in transdisciplinary research. In this way, comeniology is capable of constructing many genetic sequences, thanks to which Comenius' legacy and heritage is not only of a historical nature; it truly belongs to the valuable components of contemporary humanistic culture. On the other hand, however, the affiliation of comeniology to the humanities also has a darker side; looking at it from the scientific and methodological point of view, generalizations within it are not nomothetic.
\end{abstract}

Keywords: scientific research, humanities, historiography, comeniology

Streszczenie: Badania komeniologiczne traktuję jako należące do szeroko rozumianej humanistyki. Z racji zróżnicowania merytorycznego twórczości Komeńskiego, będącego przedmiotem wielu specjalizacji naukowych, zaliczam je do badań transdyscyplinarnych. Komeniologia jest zdolna do konstruowania ciągów genetycznych, dzięki którym dorobek i spuścizna Komeńskiego nie ma wyłącznie charakteru historycznego, lecz należy do wartościowych składników współczesnej kultury humanistycznej. Przynależność komeniologii do humanistyki ma także ciemniejszą stronę, bowiem z naukoznawczego i metodologicznego punktu widzenia generalizacje w jej obrębie nie mają charakteru nomotetycznego.

Słowa kluczowe: badania naukowe, humanistyka, historiografia, komeniologia

The problem specified in the paper title can be viewed from many perspectives. Today, we are no longer dealing with application activities, i.e. Comenius' achievements are not directly used in the creation of modern educational institutions, while the problems he poses and the solutions pro- 
posed have intellectual value, because they show how in certain cultural and historical conditions it is possible to act in a creative and original way. Comenius represents an important link in modern pedagogical culture. If we agree that there exist individual, and in relation to Comenius, also personal links forming a certain connected string, a chain that leads to the present, then it must be consistently recognized that this present is not unlimited freedom, but that its sense is also a derivative of all senses from the past. In his analyses of scientific studies, K. Ajdukiewicz, while scrutinizing methodological types in the humanities, pointed to three of them: nomotetic, evaluative and idiographic types. As far as the idiographic type is concerned, the characteristic area of research to be observed here is its historical aspect. And here, factual and descriptive research, carried out according to the model postulated by L. Ranke, has been emphasized1. Contemporary historiography, without giving up fidelity to sources, has departed far from this model aptly labeled spontaneous positivism by J. Topolski and constructs narratives initiated by J. Droysen. In place of the chronological description of events, history appears - according to M. Bloch - which is the science of people in time ${ }^{2}$. One should also pay attention, following S. Ossowski's assertions, to two possible types of historical generalizations - the first concerns phenomena limited in time and space, and here the bioxography of Comenius itself should be pointed out. At the same time the second type of generalization concerns certain genetic sequences and these transcend the perspective of one man's life and his time, cover a different space and another time, giving rise to metahistorical research $^{3}$. This problem can also be looked at from a different point of view, which ultimately leads to the articulation of these genetic sequences. I refer here to the position held byT. Gadacz, who interpreted the view of Gadamer that "in the humanities only this deserves attention, which meets the educational requirement"4, which Gadamer (and Gadacz behind him) finds in the classical Greek sense and understands as involvement, participation and experience. Understanding the present in humanities is in this perspective nothing more than participation in the procession of ideas. Comenius himself,

\footnotetext{
${ }^{1}$ K. Ajdukiewicz, Język i poznanie, Warszawa 1985, p. 311-313. The author also mentions the supporters of the nomotetic nature of history.

2 S. Sztobryn, Historiografia edukacyjna i jej metodologia. Wybrane zagadnienia, [in:] S. Palka (ed.), Podstawy metodologii badań w pedagogice, Gdańsk 2010, p. 302.

3 I presented the design of such research in a separate monograph.

4 T. Gadacz, Nauki humanistyczne między bio-, info-, techno- a „wciskaniem kitu”. Metodologiczne podstawy nauk humanistycznych, [in:] http://rep.up.krakow.pl/xmlui/bitstream/handle/ 11716/1635/01--Nauki-humanistyczne-miedzy-bio-info-techno-a-wciskaniem-kitu--Gadacz. pdf?sequence=1\&isAllowed=y p. 9, (access date 20.07.2019).
} 
all his work and his successors (both protagonists and antagonists) create such a sequence. At this point, it is worth making one caveat related to the work of a humanist-historian ${ }^{5}$. Since the elementary component of these studies is the search, collection, description and interpretation of historical facts, the quality of the resulting scientific narrative will be determined by their selection. Neocantists (such as H. Rickert) accept their culture-forming value as the criterion for selecting historical facts. Although this criterion is not explicit, it is important for comeniology. What makes sense to the modern recipient of comeniological research is precisely the understanding that the genetic sequences and individual biodoxographic facts discovered by researchers belong to living, not out-of-date culture tissue. This also includes the hermeneutics of Comenius' legacy available to a modern comeniology researcher, as the values encoded in his writings have been read by him and subjected to a comprehensible interpretation.

Interest in Comenius' pedagogical thought has been going on for several centuries. The beginnings can be traced back to his lifetime, when he reformed education in many European countries. At present, at least two nations are particularly interested in researching Comenius' life and work; these are Czechs and Poles. But you can also indicate another criterion - religious, for example. The split that took place in the bosom of Christianity set against themselves the followers of the same god, but understood differently by the believers of Catholicism and Protestantism. As the Czechs present Comenius differently from the Poles, so too will theologians not agree on everything. The binary approach to the existing sources breeds certain consequences (i.e. criticism or defense) that can be found in many comeniological texts. As it seems, the criteria for practicing comeniology can be easier indicated in a more profound way by referring to pedagogical, social, political, philosophical or religious ideas of Comenius ${ }^{6}$. Does comeniology therefore have a special place among other humanities research? Probably not. However, it has its specificity determined by the unique life path of the Moravian. Intellectual work of subsequent generations has been going on since the $17^{\text {th }}$ century, aimed at reading and using its solutions, and now hermeneutic, historical and reception research is being conducted. The extent of his intellectual activity entails a multitude of scientific fields whose representatives make a considerable

\footnotetext{
${ }^{5}$ I strongly expose this scientific discipline because comeniology is most saturated with this type of research.

6 The research area of comeniology can also be considered spatially, temporarily, personally, comparatively, and as metareflexia associated with reception studies.
} 
research effort. From this perspective - taking into account contemporary science classifications - Comenius' achievements will fall into various areas, but his greatest achievements are related to the humanities. Therefore, the status of the humanities will be important for determining the place of comeniology in the orbit of modern science, and from a methodological point of view, since comeniology is part of the humanities, it will also interiorize all its weaknesses.

The question about the place of comeniology in science is inseparably connected with the question of what we mean by science in general, as well as whether comeniology meets at least some scientific norms. The very concept of science is ambiguous; it will be mainly considered as science understood as a product or a kind of knowledge that will be different from ordinary knowledge or illumination. Social sciences and humanities, striving to be a fully scientific reflection, however, differ from natural sciences, although in the history of science there was also a period of methodological monism. The general concise formulation of E. Nagel stating that scientific knowledge equals ordered knowledge is still too general in the sense that it does not reflect the specificity of humanistic knowledge. Since the times of W. Windeland and H. Rickert, who distinguished Kulturwissenschaft and Naturwissenschaft ${ }^{7}$, this separateness has been sanctioned, and although the humanities have not achieved such a high degree of generality and theoreticality as the natural sciences, they have not been denied the right to call themselves sciences. The derivative of this division is the distinction of nomotetic and idiographic sciences. ${ }^{8}$ Comeniology being part of the humanities, uses these distinctions. In modern science we deal with axiological relativism emphasizing general, if not methodological, freedom. The consequence of this would be the abandonment of some or all of the principles that govern scientific research and which no longer distinguish such components of culture as science and poetry, or literature. Scientific cognition, however, has some specific features, thanks to which its identity is preserved and it is not reduced to rhetorical techniques with a metaphor at the forefront. There are many typologies of science and scientific standards in the literature ${ }^{9}$. T. Sozański - in relation to

\footnotetext{
7 This was the title of H. Rickert's book published many times in Tübingen; in 1926 it was the 7th edition.

8 Tatarkiewicz proposes replacing this dichotomy with another, more adequate, namely the distinction between nomological and typological sciences.

${ }^{9}$ An interesting characteristic of the typology of sciences based on the method of explanation is presented in W. Strawiński's work, Funkcja i cele nauki - zarys problematyki metodologicznej, "Zagadnienia Naukoznawstwa" 2011, No. 3.
} 
sociology - points to such norms as: rationality, intersubjective communication, regularity, consistency, completeness, certainty, decidability, empirical testability, methodology, generality, accuracy, simplicity, abstractness, universality, information wealth, originality, utility, brevity. Social sciences and humanities are not always able to entail all the norms highlighted above and cannot fully meet all of them ${ }^{10}$. The adopted standards will determine the level of education of specific studies, but will also play a selective role, distinguishing methodical and rational studies from the spontaneous expression of subjective attitudes often found there. With regard to comeniology, such an approach may be relevant where an obvious clash of historical assessments of Comenius' intentions and deeds can be observed.

The humanistic, pluralistic and transdisciplinary nature of comeniology ${ }^{11}$, its connection with sciences of various levels of development (abstraction) has its justification also in the strong relationship of all humanities with the philosophy and slow, but persistent, evolution of the isolation of individual disciplines. The rapidly progressing specialization of the sciences, which has been taking place since the beginning of the $20^{\text {th }}$ century, somehow made them independent of philosophy, but such scientific disciplines as even pedagogy are again wide open to integrative support of philosophy. This sinusoidal movement within the detailed sciences is of great importance for comeniological research because, together with the increase of factual data, it is not enough for their simple, descriptive registration, as is still the case in the field of history ${ }^{12}$. To be able to say something about the importance of the Comenius legacy for present and future generations, a synthesis integrating individual studies with an increasingly higher level of abstraction is needed. This seems to me to be a task that is facing, both Polish and global, comeniology.

\footnotetext{
10 T. Sozański, Co to jest nauka, [in:] J. Goćkowski (ed.), Nauka. Tożsamość i tradycja, Kraków 1995, p. 23-50, http://www.cyfronet.krakow.pl/ ussozans/nauka.pdf (access date 20.07.2019).

11 Research projects are referred to as "transdisciplinary, i.e. those that designate a new area of research that transcends the disciplines from which researchers come from, or which provide many significant problems as a source". Cf. M. Żegleń, Potrzeba i perspektywy badań naukoznawczych w świetle dynamicznego rozwoju nauki i technologii, „Zagadnienia Naukoznawstwa” 2017, no 2 , p. 170.

12 There is also the reverse side of this problem, consisting of any construction of a narrative mistakenly considered as having scientific roots: "the requirement of fidelity to historical sources fundamentally distinguishes historical reconstructions from literary fiction. Forgetting this elemental truth, advocates of postmodernism on the grounds of historiography simply abandon the practice of this discipline, becoming ordinary writers". cf. M. Kokowski, Między historiq a nauką: wstęp krytyczny do metodologii historii nauki, „Prace Komisji Historii Nauki Polskiej Akademii Umiejętności” 1999, p. 77.
} 
The concept of the humanities is a very broad and capacious one, covering a wide range of problems and phenomena which, when functioning within the orbit of intersocial relations, either affect a person or were generated by him in the form of texts of culture. Feedback is also involved; for Barbara Skarga, the humanities are concerned with thinking about thinking and reflecting this in the products of human spirituality. In this perspective, B. Skarga's thought is close to Gadamer's concept of theory, perceived as participation, reflection on reality ${ }^{13}$. Both concepts are about going beyond techne particularism. Gadamer also adds that the it is history which has to be recognized as the very element of humanities ${ }^{14}$, and Skarga proclaims the belief that the humanities are unique in that they are present in human nature and culture in the form of existential questions. All these theses indirectly point to Comenius' place in the stream of history that has reached modern times and which shapes our modern way of thinking 15 .

W. Tatarkiewicz drew attention to two important elements in humanities research. Contrary to the current fashion for metaphorical narrative construction, he emphasized the need for precise use of concepts, which evidently implies their precise definition. The second element in Tatarkiewicz's concept was to create a certain order in conceptually reconstructed reality, what necessitates the appearance of typological concepts ${ }^{16}$. It seems that from this terminological perspective, comeniology is still in its infancy, i.e. it has not developed a language specific to its area of research; it usually makes use of a colloquial language or bases upon the achievements of some scientific disciplines of recognized status,; and even more it has no typological concepts that constitute a higher level of generality of formulated theses. On the other hand, T. Sozański assumes the possibility of creating scientific theories based on sets of maximally systematized concepts whose starting point is the definitions of primary terms ${ }^{17}$. For comeniology, this level is unattainable today for the reasons previously stated. At the current stage of development, Polish comeniology, by describing historical phenomena and processes explaining Comenius'

\footnotetext{
${ }^{13}$ A. Węgrecka, Kryzys współczesnej humanistyki w świetle refleksji Barbary Skargi, [in:] K. Pujer (ed.), Nauki społeczne i humanistyczne wobec wyzwań XXI wieku, Wrocław 2017, p. 10.

14 Gadacz, op. cit., p. 8.

15 Maria Korytkowska presents a similar point of view. According to her, "knowledge of the achievements of ancestors in specific areas of the humanities [...] is not only a part of knowledge, but also contributes to the awareness of one's place and role in modern times". Cf. M. Korytkowska, Po co humanistyka, [in:] http://pauza.krakow.pl/387_1\&2_2017.pdf.

16 R. Kleszcz, W. Tatarkiewicz. Uwagi metafilozoficzne, „Zagadnienia Naukoznawstwa” 2017, no 1 , p. 38.

17 T. Sozański, Co to jest nauka..., op. cit.
} 
phenomenon, is able to formulate only specific statements, reliably researched and based on strong source foundations, but with a low degree of generality ${ }^{18}$..The phenomenon of interpenetration of concepts from one discipline to another called "wandering concepts" may have a special meaning for comeniology which, as far as I can se it, could function in a group of transdisciplinary research. The creator of this concept, Mieke Bal, argues that concepts remain the most vital tissue of science and their journey takes place not only between individual researchers, but also between various scientific disciplines and - which is of particular importance for comeniology - historical periods. This way of thinking opens a new perspective of comeniological research, which can be directed precisely at this journey of concepts and their evolution in time and space.

As it seems, an idea to create and develop a humanities development program has remained a considerable contemporary demand. Such a demand was made in the first decade of the $21^{\text {st }}$ century ${ }^{19}$. Currently, we are dealing with the next edition of the National Program for the Development of the Humanities (NPDH) ${ }^{20}$, the scope of which gives some chance to take up comeniological issues. For obvious reasons, this program contains its universal character and does not indicate specific problems that may (or, even should) be the subject of research, with the exception of the topics that have been previously ordered.

\footnotetext{
$18 \mathrm{~J}$. Garewicz's theory of reception, which I used in Comenius's biodoxography research, has a specific character, but it is a methodological theory introducing a hierarchical order into the historical and contemporary readings of his legacy. cf., Sztobryn S., Polska XX-wieczna recepcja pedagogiki Jana Amosa Komeńskiego, "Siedleckie Zeszyty Komeniologiczne, series pedagogika", vol. 4/2017 - Współczesne recepcje Jana Amosa Komeńskiego, p. 57-72.

19 Collective work, Nauki humanistyczne w Polsce. Założenia do programu rozwoju, p. 2, http://pau.krakow.pl/inicjatywy/Nauki_humanistyczne_2008_2009/NaukiHumWPolsce1_2009. pdf (access date 20.07.2019).

Despite the many weaknesses that the program is intended to address, Polish humanities are substantively high if we were to judge it by the position of our research in Europe and in the world. Cf. http://pauza.krakow.pl/Tabela4.pdf (access date 20.07.2019).

${ }^{20} \mathrm{NPDH}$ focuses its activities around two centers - national heritage and the introduction of outstanding Polish studies into the international circulation and the access to significant foreign texts; cf. W. Bolecki, untitled, http://pauza.krakow.pl/456_3_2019.pdf.. Ryszard Nycz has very unequivocally commented on the visible threats to borderline research, where comeniology should be included;. cf. R. Nycz, Humanistyka za kratkami (dyscyplin - według Ustawy), http://pauza.krakow.pl/441_2\&3_2018.pdf, p. 2-3 (access date 20.07.2019).

A critical approach to the competition courts in grants that evidently limit the research topics was presented by H. Samsonowicz. cf. H. Samsonowicz, Kondycja humanistyki, http://pauza. krakow.pl/60_62_3_2009.pdf, p. 3 (access date 20.07.2019).
} 


\section{References}

Ajdukiewicz Kazimierz, Language and cognition, Warszawa 1985.

Bolecki Włodzimierz, untitled, In: http://pauza.krakow.pl/456_3_2019.pdf

Gadacz Tadeusz, Humanities between bio-, info-, techno- and "bullshitting". Methodological foundations of the humanities], In: http://rep.up. krakow.pl/xmlui/bitstream/handle/11716/1635/01--Nauki-humanistyczne-miedzy-bio-info-techno-a-wciskaniem-kitu-Gadacz.pdf?sequence $=1 \&$ isAllowed $=\mathrm{y}$

Kleszcz Ryszard, Władysław Tatarkiewicz. Metaphilosophical remarks, "Issues in Science Studies" 2017, no 1.

Kokowski Michał, Between history and science: a critical introduction to the methodology of the history of science, In: The works of the Committee on the History of Science of the Polish Academy of Arts and Sciences, 1999.

Korytkowska Małgorzata, What are the humanities for?, In: http://pauza. krakow.pl/387_1\&2_2017.pdf

Nycz Ryszard, Humanities behind bars (of the disciplines - according to the Act), In: http://pauza.krakow.pl /441_2\&3_2018.pdf

Samsonowicz Henryk, The condition of the humanities, In: http://pauza. krakow.pl/60_62_3_2009.pdf

Sozański Tadeusz, Defining a science, In: J. Goćkowski (ed.), Science, identity and tradition, Kraków 1995.

Strawiński Witold, Function and aims of science - an outline of methodological issues, "Issues in Science Studies", 2011, no 3.

Sztobryn Sławomir, Educational historiography and its methodology. Selected Issues, In: S. Palka (ed.), The basis of the methodology ro research in pedagogy, Gdańsk 2010.

Sztobryn Sławomir, Polish 20th century-dating reception of Comenius' pedagogy, In: B. Sitarska (ed.), Contemporary receptions of Comenius' teachings, „Siedleckie Zeszyty Komeniologiczne, seria pedagogika”, vol. IV, Siedlce 2017, p. 57-72.

Węgrecka Aleksandra, The crisis of contemporary humanities in the light of Barbara Skarga's reflection, In: K. Pujer (ed.), Social sciences and the humanities facing the challenges of the 21 st century, Wrocław 2017.

Żegleń Urszula M., The need for and prospects for scientific research in the light of the dynamic development of science and technology, In: "Issues in Science Studies", 2017, no 2.

Collective work, Humanities in Poland. Assumptions for the development program p. 2; In: http://pau.krakow.pl/inicjatywy/Nauki_ humanistyczne_2008_2009/NaukiHumWPolsce1_2009.pdf 